\title{
TRANSLATING THE BIBLE ${ }^{1}$
}

\section{Anthony Howard Nichols}

Developments in translation theory have externalised processes used intuitively by translators for centuries. The literature on Bible translation in particular over the last half century is dominated by Eugene A. Nida and his protégés in the United Bible Societies (UBS) and Wycliffe Bible Translators whose work is informed by a wealth of inter-cultural experience.

This thesis is a critique of the Dynamic Equivalence (DE) theory of translation propounded by Nida, exemplified in the Good News Bible (GNB), and promoted in non-Western languages by the UBS. The term 'functional equivalence' has been preferred since 1986.

Section I of the thesis surveys the history of translation, its theory and problems, and describes relevant developments in linguistics. Section II examines Nida's sociolinguistic model and his methods of grammatical and semantic analysis, transfer and restructuring. Section III focuses on the translation of seven texts representing different Bible genres into the Septuagint Greek, English and Indonesian versions, respectively, noting the distinctive features of $\mathrm{DE}$ translations. Section IV takes up and examines key issues that have arisen: the nature of biblical language, the handling of important biblical motifs and technical terminology, and the practical implications of naturalness and explicitness in translation.

Nida has provided excellent discussion on most translation problems, as well as useful tools for semantic analysis. However, the DE model is found to be defective for Bible translation. Firstly, it underestimates the intricate relationship between form and meaning in language. Secondly, while evaluation of translation must take account of its purpose and intended audience, 'equivalence' defined in terms of the receptor's reactions is impossible to measure, and blurs the distinction between 'translation' and 'communication'. Thirdly, the determinative role given to receptor response constantly jeopardises

1 A.H. Nichols, Translating the Bible: A Critical Analysis of E.A. Nida's Theory of Dynamic Equivalence and Its Impact upon Recent Bible Translations (unpublished Ph.D. thesis, University of Sheffield, 1997); supervisor: Professor J.W. Rogerson. 
the historical and cultural 'otherness' of the biblical text. Finally, the emphasis on explicitness in UBS and Summer Institute of Linguistics manuals in practice guarantees that indigenous receptors approach Scripture through a Western grid and denies them direct access to the biblical universe of discourse. Hence, in one important point the results of the investigation were totally different from the researcher's original premise. It had been anticipated that Nida's emphasis on naturalness, communication and receptor response would lead to cultural adaptation and a domestication of the Bible in each target language. Clear indications of this tendency were noted in the GNB (e.g. the radical restructuring of sentences, the dissipation of central motifs and images and their replacement by lengthy paraphrases, the elimination of anthropomorphic references to God, as well as such formal features as repetition, formulae, chiasmus and key words). But surprisingly there was almost no evidence of such domestication in the Indonesian versions or the other recent non-European versions looked at. In fact, the renderings of the more traditional, 'formal correspondence' Indonesian versions were regularly more culturally appropriate. Rather, what emerged was the immense influence of the GNB on three important non-Western versions, the Indonesian and (to the extent they were consulted) the Malay and Chinese versions. GNB renderings were found to be regularly reproduced to such an extent that it seems to have been not just a model but the actual base for translation, rather than the source text. This is despite the claim in the prefaces that the translators worked from the original languages. The result is that the indigenous receptors must approach Scripture through a Western grid.

The whole issue of subjectivity and ideology in translation has attracted the attention of poststructuralist linguists. Basil Hatim has complained that Anglo-American publishers force translators to obliterate the original text of modern Arabic literature with their insistence on fluency, transparency, logic, and explicitness. Likewise, Lawrence Venuti has described the grossly unequal exchanges between the hegemonic English language nations, particularly the United States, and the other nations of Europe, Africa, Asia and Latin America. He claims that to have any chance of being translated, one must be intelligible within the outlook of American ideology. The analogy with Bible translation is not a comfortable one. But it raises the question as to whether the promotion of $\mathrm{DE}$ translation procedures has become an unwitting instrument of this Western cultural hegemony. 